\title{
God se toorn in die Ou Testament
}

\section{Book Title:}

Traag tot toorn

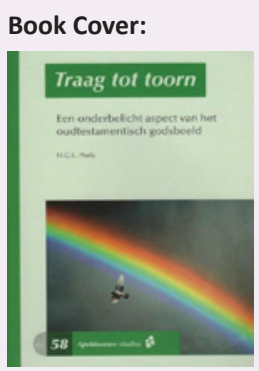

Author:

H.G.L. Peels

ISBN:

9789075847352

Publisher:

Apeldoorn: Theologische

Universiteit, 2011, €9.95*

*Book price at time of review

Review Title:

God se toorn in die Ou

Testament

Reviewer:

Herrie F. van Rooy ${ }^{1}$

\section{Affiliation:}

${ }^{1}$ Faculty of Theology,

North-West University,

Potchefstroom Campus,

South Africa

Email:

herrie.vanrooy@nwu.ac.za

Postal address:

Faculty of Theology,

North-West University,

Potchefstroom 2520,

South Africa

How to cite this book review: Van Rooy, H.F., 2012, 'God se toorn in die Ou Testament', In die Skriflig/In Luce Verbi 46(1), Art. \#126, 1 page. http//dx.doi.org/ 10.4102/ ids.v46i1.126

(C) 2012. The Authors. Licensee: AOSIS OpenJournals. This work is licensed under the Creative Commons Attribution License.
Hierdie gepubliseerde voordrag is gelewer by die opening van die akademiese jaar 2011-2012 van die Theologische Universiteit Apeldoorn. Dit handel oor die lankmoedigheid van God, 'n tema wat nie voldoende aandag gekry het in die openbaringsgeskiedenis van die Ou Testament nie. Die woord lankmoedigheid word gebruik as vertaling van 'n Hebreeuse konstruksie wat letterlik sou kon beteken 'traag tot toorn', soos die titel van die boek lui. Die studie handel in die besonder oor God se lankmoedigheid, wat Hom daartoe bring om nie die oordeel onmiddellik te voltrek nie, maar dit uit te stel. Die begrip lankmoedigheid hou verband met God se geduld en sy vergewensgesindheid, waardeur Hy steeds aan die mens geleentheid gee om tot bekering te kom.

Die betrokke term word net in die wysheidsliteratuur, spesifiek Spreuke en Prediker, ten opsigte van mense gebruik. By mense het dit altyd 'n positiewe betekenis, in die sin van selfbeheersing, mildheid en vergewensgesindheid. Die term word ten opsigte van God gebruik in al drie dele van die Hebreeuse kanon, naamlik die Wet, Profete en Geskrifte. Wat die gebruik ten opsigte van God betref, gaan Peels uit van die bekende formule in Eksodus 34:6-7:

Ek, die Here, is die barmhartige en genadige God, lankmoedig, vol liefde en trou. Ek betoon my liefde aan geslagte en geslagte. Ek vergewe ongeregtigheid, oortreding en sonde, maar Ek spreek niemand sonder meer vry nie. Ek reken kinders en kleinkinders die sondes van vaders toe selfs tot in die derde en vierde geslag.

Hy wys daarop dat hierdie gedeelte sewe keer in die Ou Testament aangehaal word, terwyl gedeeltes daarvan nog ruim 20 keer voorkom. Hierdie formule is 'n selfopenbaring van God en dui op sy liefdevolle houding teenoor sy volk. Daar is steeds die moontlikheid van oordeel en straf, maar die oordeel en straf word in verband met God se lankmoedigheid gebring. Die oordeel en straf kom, maar word op grond van God se lankmoedigheid uitgestel. Hierna kyk Peels hoe die credo van Eksodus 34 eksplisiet na vore kom in ander gedeeltes van die Ou Testament, met verwysing na tekste soos Psalm 68, Psalm 103, Numeri 14, Nehemia 9 en Miga 2. Uitstel van die oordeel beteken nie afstel daarvan nie. God kan selfs lankmoedig wees teenoor die vyande van die volk, soos Jona gekla het. Hy kyk ook na gedeeltes waar God se lankmoedigheid nie eksplisiet genoem word nie, maar waar dit wel 'n rol speel. Die geskiedenis van die mens se sondeval is hiervan 'n goeie voorbeeld. Toe die mens gesondig het, het die straf nie onmiddellik in werking getree nie. Daar was eers genadetyd, en die genade was juis moontlik weens God se lankmoedigheid.

Aan die einde van die boek word 'n aantal belangrike gevolgtrekkings gemaak. Die idee van lankmoedigheid is inderdaad 'n belangrike motief in die Ou Testament. Dit het ook 'n baie positiewe inhoud. God se lankmoedigheid onderskei Hom van die afgode van daardie tyd: lankmoedigheid was nie deel van die kernsamestelling van die afgode nie. Vir die Godsbeeld van die Ou Testament is God se lankmoedigheid dus ook belangrik, juis omdat dit sy genade beklemtoon en sy oordeel meer op die agtergrond skuif.

Die besondere waarde van hierdie werk is geleë in die aandag wat dit gee aan 'n tema wat in die bestudering van die openbaringsgeskiedenis van die Ou Testament te min aandag gekry het. Die studie is op'n omvattende, indringende en deeglike wyse gedoen, met belangrike gevolgtrekkings. Miskien sou die skrywer meer aandag kon gegee het aan die valse teenstelling wat tussen die $\mathrm{Ou}$ en Nuwe Testament as wet en evangelie gemaak word. Die evangelie, die verkondiging van God se genade, is inherent deel van die boodskap van die Ou Testament. Hierdie werk kan aanbeveel word vir teoloë en predikante. Dit is egter ook geskik vir die algemene kerklike leserspubliek. 